\title{
Liquid Crystal-Infused Porous Polymer Surfaces: A "Slippery" Soft Material Platform for the Naked-Eye Detection and Discrimination of Amphiphilic Species
}

Harshit Agarwal, ${ }^{1}$ Kayleigh E. Nyffeler, ${ }^{2}$ Uttam Manna, ${ }^{1, \#}$ Helen E. Blackwell, ${ }^{2,}$ and David M. Lynn ${ }^{1,2, *}$

${ }^{1}$ Dept. of Chemical \& Biological Engineering, Univ. of Wisconsin-Madison, 1415 Engineering Dr., Madison, WI 53706 USA; ${ }^{2}$ Dept. of Chemistry, Univ. of Wisconsin-Madison, 1101 University Ave., Madison, WI 53706 USA; ${ }^{\sharp}$ Current Address: Department of Chemistry, Indian Institute of Technology-Guwahati, Guwahati, Assam-781039, India. E-Mail: (H.E.B.) blackwell@chem.wisc.edu; (D.M.L)dlynn@engr.wisc.edu

\section{SUPPORTING INFORMATION}

Table S1. Bacterial strain and plasmids used in this study.

\begin{tabular}{|c|c|c|c|}
\hline & $\begin{array}{l}\text { Referred to } \\
\text { herein }\end{array}$ & Description & $\begin{array}{l}\text { Reference or } \\
\text { Source }\end{array}$ \\
\hline \multicolumn{4}{|c|}{ Staphylococcus aureus } \\
\hline RN6390b & S. aureus WT & $\begin{array}{l}\text { Wild type, agr group I } \\
\text { (NTCC } 8325 \text { cured of prophages }^{1} \text { ) }\end{array}$ & Novick $^{2}$ \\
\hline RN9222 & QS mutant & RN6911 with pRN7062 & Lyon et al. ${ }^{3}$ \\
\hline RN6911 & $\mathrm{N} / \mathrm{A}$ & $\begin{array}{l}\text { agr::tetM, from RN6390b (agr- } \\
\text { null) }\end{array}$ & Novick et al. \\
\hline \multicolumn{4}{|l|}{ Plasmid } \\
\hline pRN7062 & QS mutant & $\begin{array}{l}\text { Contains agrCA and } P 3-b l a Z \\
\text { fusion }\end{array}$ & Lyon et al. $^{3}$ \\
\hline \multicolumn{4}{|c|}{ Pseudomonas aeruginosa } \\
\hline PAO1 & $\mathrm{N} / \mathrm{A}$ & Wild type, isolated from wound & Holloway $^{4}$ \\
\hline mPAO1 & PAO1, WT & $\begin{array}{l}\text { Wild type, derivative of } \\
\text { Holloway's isolate }\end{array}$ & $\begin{array}{l}\text { Gift from E.P. } \\
\text { Greenberg }\end{array}$ \\
\hline PAO1-T & $\mathrm{N} / \mathrm{A}$ & $\begin{array}{l}\text { Wild type, derivative of } \\
\text { Holloway's isolate }\end{array}$ & $\begin{array}{l}\text { WT from PA } \\
\text { two-allele } \\
\text { library }^{6-7}\end{array}$ \\
\hline PAO-SC4 & $\Delta l a s I \Delta r h l I$ & In-frame deletions of lasI and rhlI & $\begin{array}{l}\text { Gift from E.P. } \\
\text { Greenberg }\end{array}$ \\
\hline PAO1 $\Delta r h l B$ & $\Delta r h l B$ & Unmarked, in-frame $r h l B$ deletion & Smalley et al. \\
\hline $\begin{array}{l}\mathrm{PAO} 1-\mathrm{T} \Delta r h l A \\
(\mathrm{PW} 6886)\end{array}$ & $\Delta r h l A$ & rhlA-E08::IsphoA/hah & $\begin{array}{l}\text { PA two-allele } \\
\text { library }\end{array}$ \\
\hline
\end{tabular}




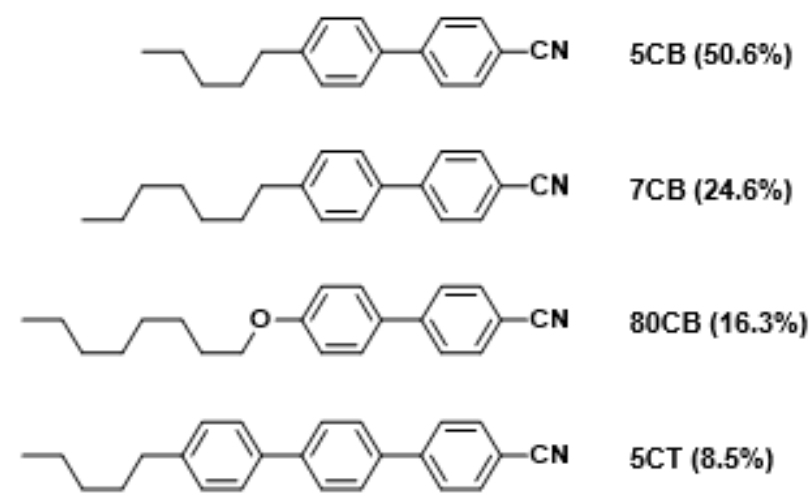

Figure S1. Thermotropic liquid crystal E7 is a proprietary combination of four different liquid crystals - 5CB, 7CB, $80 \mathrm{CB}$, and $5 \mathrm{CT}$.
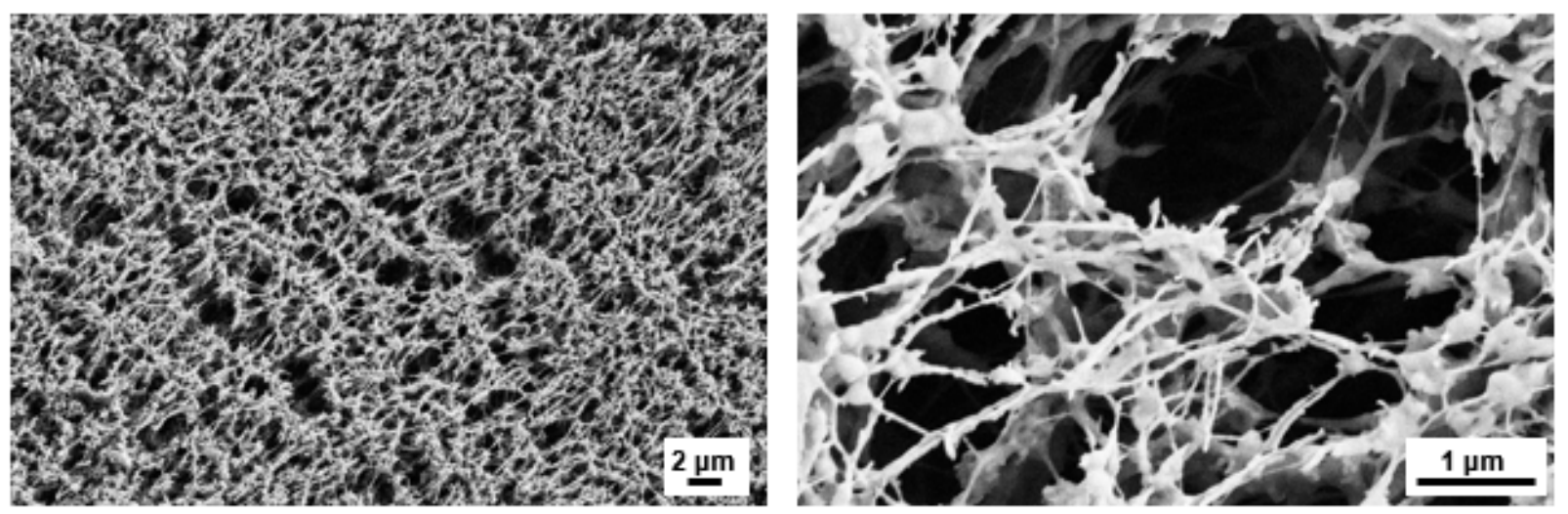

Figure S2. Low and high magnification 'top-down' SEM images of PTFE membrane showing nanoporosity. 
Table S2. Evaluation of the stability of 5CB-and E7-SLIPS in presence of water droplets.

\begin{tabular}{ccc}
\hline Parameters & 5CB-SLIPS & E7-SLIPS \\
\hline$\Theta_{\mathrm{ws}(\mathrm{a})}$ & $114 \pm 1$ & $114 \pm 1$ \\
$\Theta_{\mathrm{os}(\mathrm{a})}$ & $51 \pm 3$ & $48 \pm 3$ \\
$\gamma_{\mathrm{ow}}$ & $28.1 \pm 0.4$ & $27.5 \pm 0.8$ \\
$\gamma_{\mathrm{oa}}$ & $31.2 \pm 0.6$ & $29 \pm 0.5$ \\
$\gamma_{\mathrm{wa}}$ & $72.1 \pm 0.2$ & $72.1 \pm 0.2$ \\
$\mathrm{~S}_{\mathrm{os}(\mathrm{w})}$ & $20.8 \pm 5.7$ & $21.2 \pm 5.8$ \\
\hline
\end{tabular}

Note: Unit of contact angle is in degree. The contact angles are measured on a flat smooth PTFE surface using $5 \mu \mathrm{L}$ water droplet for $\Theta_{\mathrm{ws}(\mathrm{a})}$ and $5 \mu \mathrm{L} 5 \mathrm{CB}$ and $\mathrm{E} 7$ for $\Theta_{\mathrm{os}(\mathrm{a})}$. The unit of surface tension and interfacial tension is $\mathrm{mN} / \mathrm{m}$. Surface tension $\left(\gamma_{\text {oa }}, \gamma_{\mathrm{wa}}\right)$ and interfacial tension $\left(\gamma_{\text {ow }}\right)$ measurements were performed by the pendant drop method at ambient conditions (temperature $=$ 22 to $24{ }^{\circ} \mathrm{C}$ and relative humidity $=12$ to $20 \%$ ). Density of water used for measurements was $0.997 \mathrm{gm} / \mathrm{ml}$ and density of $5 \mathrm{CB}$ and E7 is $1.03 \mathrm{gm} / \mathrm{ml}$. The values denote mean of three independent measurements and error denotes standard deviation. $S_{\mathrm{os}(\mathrm{w})}=\gamma_{\mathrm{oa}} \cos \Theta_{\mathrm{os}(\mathrm{a})}-\gamma_{\mathrm{wa}} \cos$ $\Theta_{\mathrm{ws}(\mathrm{a})}-\gamma_{\mathrm{ow}} \geq 0$ and the units of $\mathrm{S}_{\mathrm{os}(\mathrm{w})}$ is in $\mathrm{mN} / \mathrm{m}$. $\Theta_{\mathrm{os}(\mathrm{a})}>0$ suggests that surface of PTFE membrane can emerge out of the lubricating liquid phase into air. 


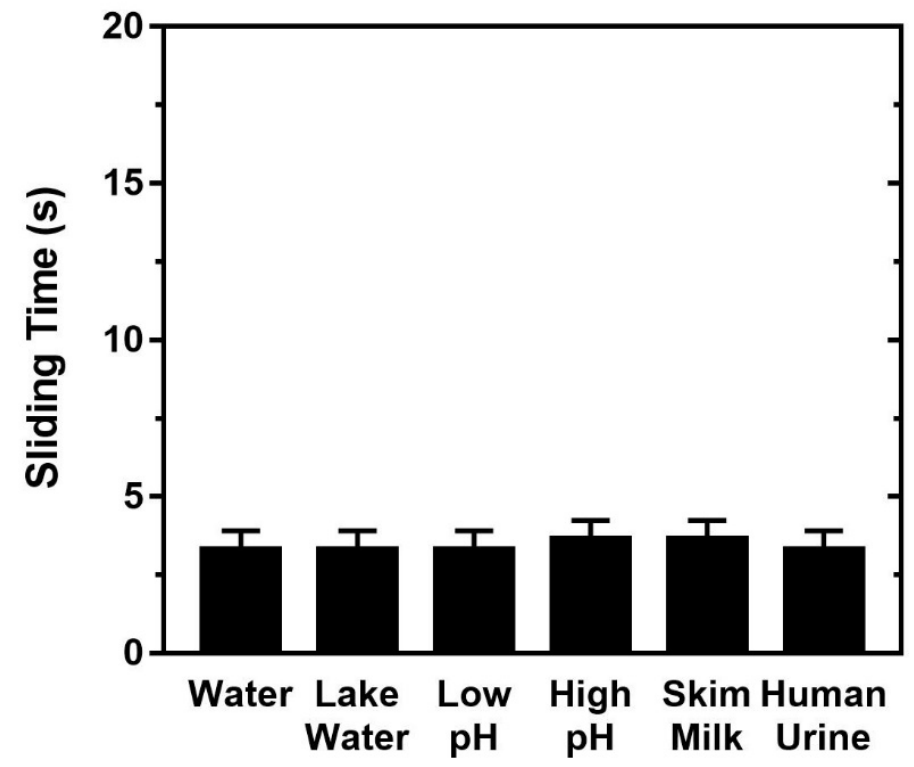

Figure S3. Plot showing sliding time of $50 \mu \mathrm{L}$ droplets of various liquids (Milli-Q water, unfiltered eutrophic lake water, acidic $(\mathrm{pH} 1)$ and alkaline $(\mathrm{pH} 11)$ solution, skim milk and pooled human urine) sliding on E7-infused SLIPS tilted at $20^{\circ}$.
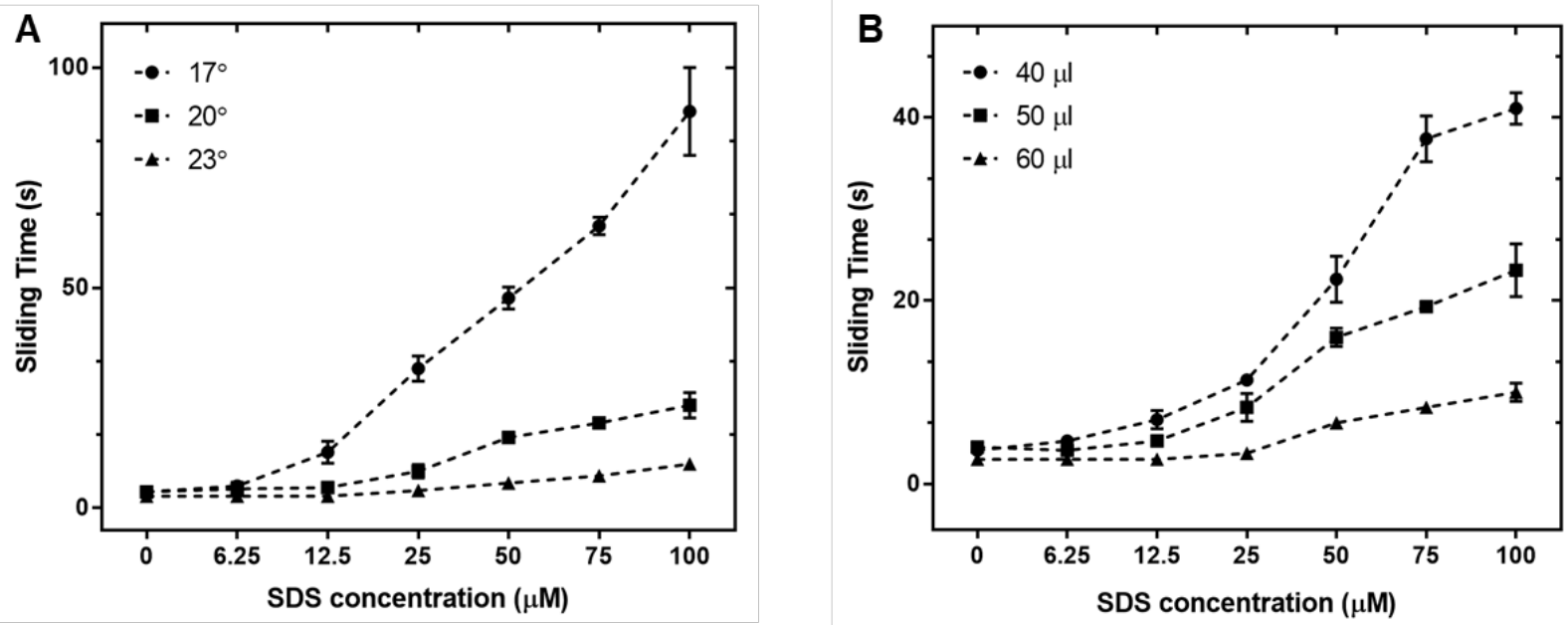

Figure S4. Plot showing the sliding time as a function of the concentration of SDS in PBS droplets for (A) different tilt angles $\left(17^{\circ}, 20^{\circ}\right.$, and $\left.23^{\circ}\right)$ at a fixed droplet volume $(50 \mu \mathrm{L})$ and $(\mathrm{B})$ different droplet volumes $(40 \mu \mathrm{L}, 50 \mu \mathrm{L}$, and $60 \mu \mathrm{L})$ at a fixed tilt angle $\left(20^{\circ}\right)$. 
A

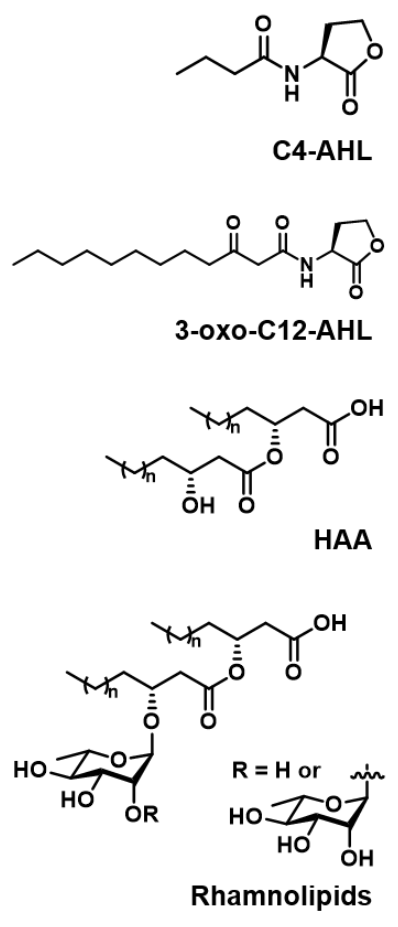

B

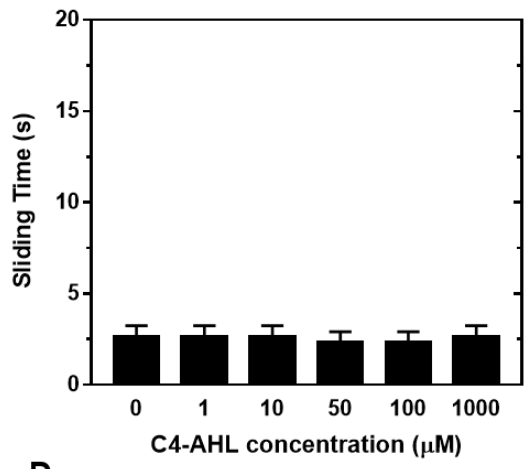

D

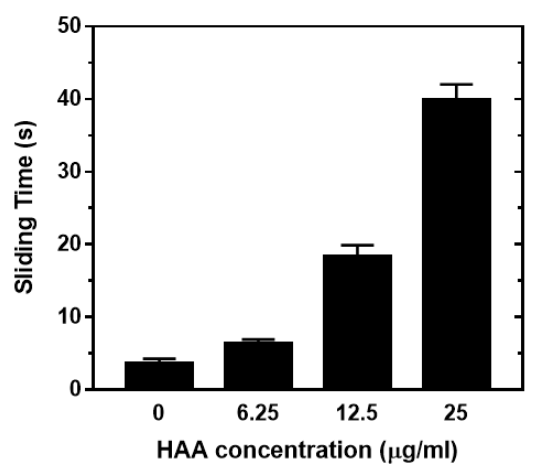

C

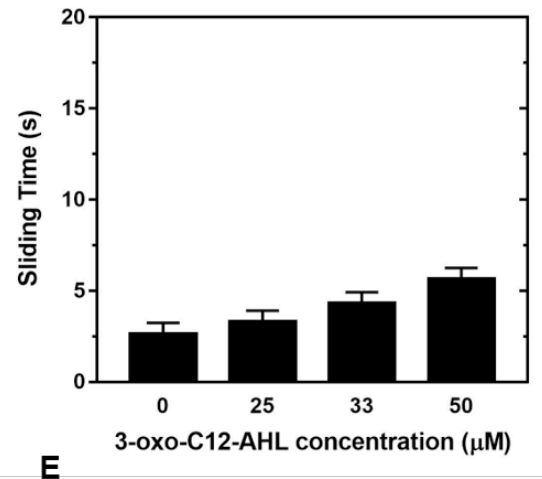

E

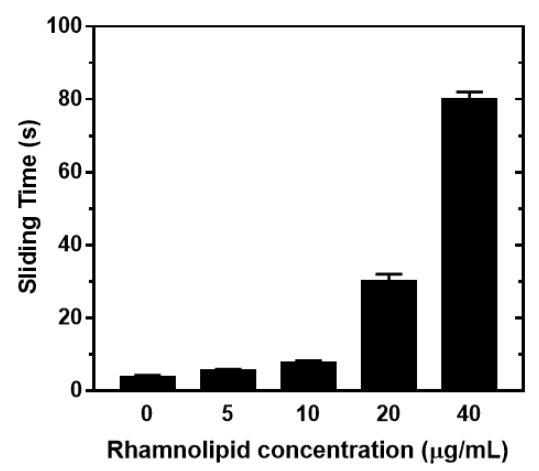

Figure S5. (A) Structures of the AHLs and bacterial biosurfactants investigated in this study ( $\mathrm{n}=$ 3-11 for rhamnolipid and HAA). HAA was evaluated as a mixture of stereoisomers (see Materials and Methods). (B-F) Plots showing sliding time of droplets of (B) C4-AHL, (C) 3-oxoC12-AHL, (D) HAA, and (E) rhamnolipids on E7-infused SLIPS. $50 \mu \mathrm{L}$ droplets of C4-AHL, 3oxo-C12-AHL and HAA solutions were used for the sliding time measurements and the SLIPS were tilted at angle of $20^{\circ}$. For measuring the sliding time of rhamnolipid solutions $42 \mu \mathrm{L}$ droplets were used and the SLIPS were inclined to $15^{\circ}$. 


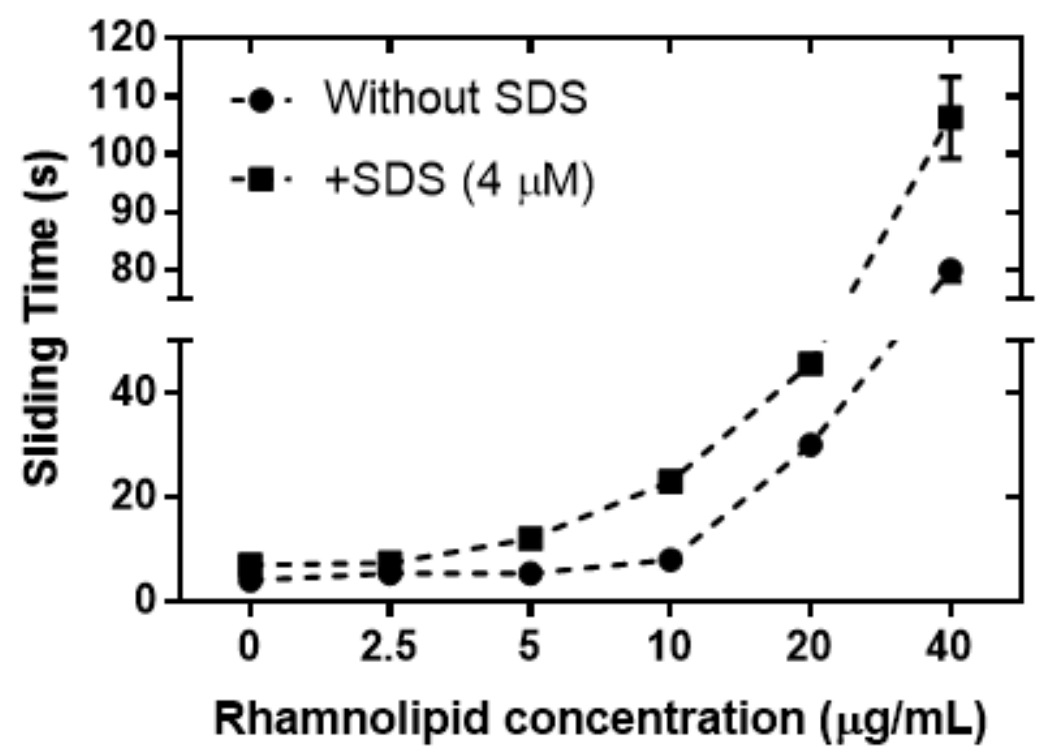

Figure S6. Plot showing the sliding time of rhamnolipid $(0-40 \mu \mathrm{g} / \mathrm{ml})$ containing droplets on LC-SLIPS with SDS ( $4 \mu \mathrm{M}$; black squares) and without SDS (black circles). $42 \mu \mathrm{L}$ droplets were used in each case and the SLIPS tilt angle was fixed at $15^{\circ}$.

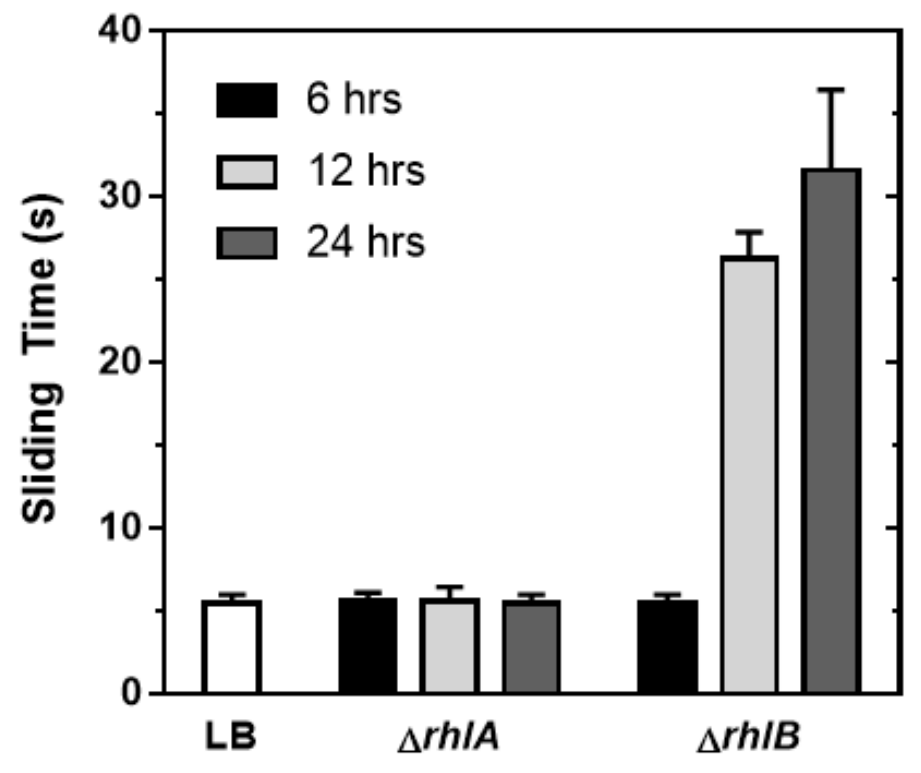

Figure S7. Plot showing the sliding time of LB media, $\Delta r h l A$, and $\Delta r h l B$ at $6 \mathrm{hrs}$ (black), $12 \mathrm{hrs}$ (light gray), and 24 hrs (dark gray). $35 \mu \mathrm{L}$ droplets were used in each case and the LC-infused SLIPS was tilted to $20^{\circ}$. 


\section{Supporting Videos}

Video S1. Video showing $50 \mu \mathrm{L}$ droplets of PBS and PBS droplets containing $100 \mu \mathrm{M}$ SDS sliding down E7-infused SLIPS tilted at $15^{\circ}$.

Video S2. Video showing $50 \mu \mathrm{L}$ droplets of PBS (colored green) and PBS droplets containing $100 \mu \mathrm{M}$ SDS (colored red) sliding down E7-infused SLIPS tilted at $20^{\circ}$.

Video S3. Video showing $35 \mu \mathrm{L}$ droplets of WT P. aeruginosa culture (4x diluted in LB media before measuring the sliding time) (colored blue) and QS-mutant (4rhlI lasI) (colored orange) sliding on E7-infused SLIPS tilted at $20^{\circ}$. Companion to still images shown in Figure 3C.

Video S4. Video showing $35 \mu \mathrm{L}$ droplets of $S$. aureus WT (2x diluted in BHI media before measuring the sliding time) (colored blue) and QS mutant (lacking AgrBD, proteins critical for QS) (colored orange) sliding on E7-infused SLIPS tilted at $20^{\circ}$.

Video S5. Video showing $35 \mu \mathrm{L}$ droplets of $S$. aureus WT cultured with AIP-III D4A (at a concentration of $1 \mu \mathrm{M}$ ) (colored green) and QS mutant (lacking AgrBD, proteins critical for QS) (colored orange) sliding on E7-infused SLIPS tilted at $20^{\circ}$. 


\section{References}

1. Novick, R. P.; Ross, H. F.; Projan, S. J.; Kornblum, J.; Kreiswirth, B. N.; Moghazeh, S., Synthesis of staphylococcal virulence factors is controlled by a regulator RNA molecule. EMBO J. 1993, 12 (10), 3967-3975.

2. Novick, R. P., Properties of a Cryptic High-Frequency Transducing Phage in Staphylococcus aureus. Virology 1967, 33, 155-166.

3. Lyon, G. J.; Mayville, P.; Muir, T. W.; Novick, R. P., Rational design of a global inhibitor of the virulence response in Staphylococcus aureus, based in part on localization of the site of inhibiton to the receptor-histidine kinase, AgrC. Proc Natl Acad Sci U S A 2000, 97 (24), 13330-13335.

4. Holloway, B., Genetic recombination in Pseudomonas aeruginosa. Microbiology 1955, 13 (3), 572-581.

5. Ortiz, B. J.; Boursier, M. E.; Barrett, K. L.; Manson, D. E.; Amador-Noguez, D.; Abbott, N. L.; Blackwell, H. E.; Lynn, D. M., Liquid Crystal Emulsions That Intercept and Report on Bacterial Quorum Sensing. ACS Appl. Mater. Interfaces 2020, 12 (26), 29056-29065.

6. Jacobs, M. A.; Alwood, A.; Thaipisuttikul, I.; Spencer, D.; Haugen, E.; Ernst, S.; Will, O.; Kaul, R.; Raymond, C.; Levy, R.; Chun-Rong, L.; Guenthner, D.; Bovee, D.; Olson, M. V.; Manoil, C., Comprehensive transposon mutant library of Pseudomonas aeruginosa. Proc Natl Acad Sci U S A 2003, 100 (24), 14339-44.

7. Held, K.; Ramage, E.; Jacobs, M.; Gallagher, L.; Manoil, C., Sequence-verified two-allele transposon mutant library for Pseudomonas aeruginosa PAO1. J. Bacteriol. 2012, 194 (23), 6387-9.

8. Smalley, N. E.; An, D.; Parsek, M. R.; Chandler, J. R.; Dandekar, A. A., Quorum Sensing Protects Pseudomonas aeruginosa against Cheating by Other Species in a Laboratory Coculture Model. J. Bacteriol. 2015, 197 (19), 3154-9. 